\title{
A comparison of ondansetron and prochlorperazine for the prevention of nàusea and vomiting after tympanoplasty
}

Purpose: To evaluate the effects on PONV and headache after tympanoplasty of prochlorperazine $0.2 \mathrm{mg} \cdot \mathrm{kg}^{-1} \mathrm{im}$, ondansetron $0.06 \mathrm{mg} \cdot \mathrm{kg}^{-1}$ iv or placebo (isotonic saline) 0.02 $\mathrm{ml} \cdot \mathrm{kg}^{-1}$ iv given immediately after induction of anaesthesia prior to tracheal intubation.

Methods: The study was randomised, double blind and prospective. One hundred and forty-eight patients, aged 9-6I $y r$, received a standardised balanced inhalational anaesthetic with controlled ventilation and induced hypotension. Postoperatively, the frequencies of retching and vomiting in the PACU and of nausea, retching, vomiting, headache, analgesic and antiemetic requirements in the surgical ward for 24 hr were recorded.

Results: The four test groups ( $n=37$ each) were comparable. The incidences of vomiting in the PACU were similar. During the first $24 \mathrm{hr}$ after surgery the antiemetics produced no reductions in the incidence of nausea alone or of vomiting alone. However, the combination of nausea and vomiting was reduced from 53\% (placebo) to $16 \%$ ( $P<0.0005), 19 \%(P<$ $0.0005)$ and $30 \%(P<0.05)$ by im. prochlorperazine, iv ondansetron and iv prochlorperazine, respectively. The frequency of those experiencing no PONV was increased from $27 \%$ (placebo) by prochlorperazine im to $57 \%(P<0.01)$, by ondansetron iv to $62 \%(P<0.005)$ and by prochlorperazine iv

\section{Key words}

ANTIEMETICS: ondansetron, prochlorperazine;

COMPLICATIONS: postoperative nausea, vomiting,

headache;

SURGERY: tympanoplasty.

From the Department of Anaesthesia, Armed Forces Hospital, P.O. Box 7897, Riyadh 11159, Kingdom of Saudi Arabia.

Address correspondence to: Dr. A.A. van den Berg.

Presented, in part, at the 3rd European Society of

Anaesthesiologists Meeting. Paris - April 29th - May 3rd, 1995.

Accepted for publication Sth May, 1996. to $43 \%(P=N S)$. The onset of PONV was delayed in those given prochlorperazine im, and vomiting was less severe in those given ondansetron iv. Headache occurred with similar frequency in each group.

Conclusion: Prophylactic prochlorperazine $0.2 \mathrm{mg} \cdot \mathrm{kg}^{-1}$ im and ondansetron $0.06 \mathrm{mg} \cdot \mathrm{kg}^{-1}$ iv are similarly efficacious in reducing nausea with vomiting after tympanoplasty, while prochlorperazine $0.1 \mathrm{mg} \cdot \mathrm{kg}^{-1}$ iv is less efficacious. Neither drug given as described appeared to reduce the frequency of postoperative nausea alone or vomiting alone.

Objectif: Évaluer après la tympanoplastie l'effet sur les nausées et vomissements postopératoires (NVPO) de la prochlorpérazine $0,2 \mathrm{mg} \cdot \mathrm{kg}^{-1} \mathrm{im}$, de l'ondansetron 0,06 $\mathrm{mg} \cdot \mathrm{kg}^{-1}$ iv ou d'un placebo (soluté isotonique) $0,02 \mathrm{mg} \cdot \mathrm{kg}^{-1}$ iv administrés immédiatement après l'induction de l'anesthésie et avant l'intubation de la trachée.

Méthodes: L'étude était aléatoire, prospective et en double aveugle. Cent quarante-huit patients, àgés de neuf à 61 ans ont reçu une anesthésie équilibrée standardisée avec ventilation contrôlée et hypotension délibérée. En postopératoire, ont été enregistrés, à l'unité des soins postanesthésiques (USPA), la fréquence des efforts pour vomir et les vomissements; pendant 24 h, la fréquence des nausées, des efforts pour vomir, des vomissements, de la céphalée, les analgésiques et antiémétiques requis.

Résultats: Les quatre groupes $(n=37)$ étaient comparables. L'incidence des vomissements à l'USPA était identique. Pendant les premieres 24 après la chirurgie, les antiémétiques n'ont modifié ni l'incidence des nausées considérées indépendamment ni celle des vomissements seuls. Cependant, l'association des nausées et de vomissements était réduite de 53\% (placebo) à 16\% $(P<0,0005), 19 \%(P<0,005)$ et 30\% $(P<0,05)$, respectivement par la prochlorpérazine im, l'ondensetron iv et la prochlorpérazine iv. L'incidence d'absence de NVPO augmentait de $27 \%$ (placebo) avec la prochlorpérazine im à $57 \%(P<0,01)$, avec l'ondensetron iv à $62 \%(P$ $<0,005)$ et avec la prochlopérazine iv à $43 \%(P=N S)$. 
L'apparition des NVPO était retardée par la prochlorpérazine im, et les vomissements étaient moins importants avec l'ondensetron iv. Les céphalées survenaient à une fréquence identique dans tous les groupes.

Conclusion: L'administration prophylactique de prochlorpérazine $0,2 \mathrm{mg} \cdot \mathrm{kg}^{-1}$ im et d'ondensetron $0,06 \mathrm{mg} \cdot \mathrm{kg}^{-1}$ iv est également efficace pour réduire les nauseés et les vomissements après la tympanoplastie, alors que celle de la prochlorpérazine $0,1 \mathrm{mg} \cdot \mathrm{kg}^{-1}$ iv l'est moins. Aucun des médicaments administrés de la façon décrite réduit les nausées et les vomissements lorsqu'ils sont considérés indépendamment.

Postoperative nausea and vomiting (PONV) is a frequent and debilitating consequence of middle ear surgery. In this institution about $60 \%$ of patients experience emesis and about $50 \%$ experience headache after tympanoplasty. ${ }^{1,2}$ In anaesthetic practice PONV is commonly prevented or treated using the antidopaminergic drugs droperidol, metoclopramide or prochlorperazine. ${ }^{3}$ Of these prochlorperazine $0.2 \mathrm{mg} \cdot \mathrm{kg}^{-1} \mathrm{im}$ or 0.1 $\mathrm{mg} \cdot \mathrm{kg}^{-1}$ iv are considered to be the most efficacious, ${ }^{3}$ and have proved to be so in this hospital. ${ }^{4}$ Its use, however, as with all antidopaminergic drugs, may induce extrapyramidal (iatrogenic) reactions. Ondansetron is a newer antiemetic derived from cocaine and metoclopramide, which exerts its effect via antagonism of five hydroxy-tryptamine subtype $3\left(5-\mathrm{HT}_{3}\right)$ receptors, while exhibiting no cholinergic, adrenergic, dopaminergic or histaminergic effects. ${ }^{5}$ Though not likely to induce extrapyramidal reactions, its mode of action may increase the incidence of postoperative headache. ${ }^{6.7}$

Ondansetron has been shown to be superior as a prophylactic antiemetic than metoclopramide ${ }^{8}$ and droperi$\mathrm{dol}^{9}$ in gynaecological patients. The relative antiemetic efficacies of ondansetron and prochlorperazine have not been studied, especially in middle ear surgery where PONV constitutes a major postoperative morbidity. This study was undertaken to compare the antiemetic efficacies and effects on postoperative headache of ondansetron $0.06 \mathrm{mg} \cdot \mathrm{kg}^{-1} \mathrm{iv},{ }^{10}$ prochlorperazine $0.2 \mathrm{mg} \cdot \mathrm{kg}^{-1}$ im (as per licensing regulations in Europe) and prochlorperazine $0.1 \mathrm{mg} \cdot \mathrm{kg}^{-1}$ iv (as per licensing regulations in North America), ${ }^{11}$ each given with induction of general anaesthesia for tympanoplasty.

\section{Methods}

With Hospital Ethics Committee approval and written, informed consent of patient or guardian, 148 consecutive Saudi nationals presenting for elective tympanoplasty were studied between January 1994 and July 1995. Inclusion criteria consisted of ASA physical class 1 or 2 men and non-pregnant women. Patients were excluded from the study if they had received any antiemetic medication within $24 \mathrm{hr}$ of surgery. Patients were visited on the afternoon before surgery, the nature of the investigation explained, consent obtained and a history of motion sickness or PONV enquired into. On arrival in the operating theatre each patient was block randomised to receive saline (as placebo) or one of the three antiemetic formulations immediately following induction of anaesthesia.

Premedication comprised temazepam $\left(0.5 \mathrm{mg} \cdot \mathrm{kg}^{-1}\right.$ to the nearest $10 \mathrm{mg}$ ) po and EMLA cream applied topically to the dorsum of the left hand approximately $1.5 \mathrm{hr}$ before surgery. In theatre, routine monitoring devices (ECG, Hewlett Packard 80300A: blood pressure, Dinamap Critikon 1846: oxygen saturation, Ohmeda Biox 3700) were applied, a pre-induction value of heart rate and blood pressure recorded, an intra-venous cannula inserted and pre-oxygenation commenced.

Anaesthesia was induced and deliberate (controlled) hypotension commenced, with thiopentone (4.0 $\left.\mathrm{mg} \cdot \mathrm{kg}^{-1}\right)$, atracurium $\left(0.6 \mathrm{mg} \cdot \mathrm{kg}^{-1}\right)$, nalbuphine $(0.2$ $\left.\mathrm{mg} \cdot \mathrm{kg}^{-1}\right)$ and labetalol $\left(1 \mathrm{mg} \cdot \mathrm{kg}^{-1}\right) i v$, after which the appropriate test drug was administered (ondansetron iv $0.06 \mathrm{mg} \cdot \mathrm{kg}^{-1}$, prochlorperazine $0.2 \mathrm{mg} \cdot \mathrm{kg}^{-1} \mathrm{im}$, prochlorperazine $0.1 \mathrm{mg} \cdot \mathrm{kg}^{-1}$ iv or saline $1-2 \mathrm{ml} i v$ ). The larynx was then sprayed with aerosolized lidocaine $(10 \%)^{12}$ and an endotracheal tube inserted. Anaesthesia was maintained with nitrous oxide (67\%) and isoflurane $(0.8 \%)$ in oxygen administered via controlled ventilation using an Ohmeda AV7700 Ventilator with a respiratory rate of 8 to 12 breaths per minute, an inspiratory:expiratory ratio of $1: 3$, a tidal volume of $10 \mathrm{ml} \cdot \mathrm{kg}^{-1}$ and a fresh gas flow of $70 \mathrm{ml} \cdot \mathrm{kg}^{-1} \cdot \mathrm{min}^{-1}$ using a Bain Circuit to maintain an end-tidal carbon dioxide concentration of $4.5-5.0 \mathrm{kPa}$ (Hewlett Packard 47210A Capnometer). Ringer-lactate was infused intraoperatively at a rate of $8 \mathrm{ml} \cdot \mathrm{kg}^{-1} \cdot \mathrm{hr}^{-1}$ and dextrose-saline infused postoperatively at a rate of 2.0 $\mathrm{ml} \cdot \mathrm{kg}^{-1} \cdot \mathrm{hr}^{-1}$ until oral fluids were tolerated.

At the commencement of surgery the operating table was inclined to a $10^{\circ}$ anti-Trendelenburg (head-up) position and glyceryl trinitrate $(50 \mathrm{mg}$ glyceryl trinitrate in $500 \mathrm{ml}$ dextrose $5 \%$ saline $0.225 \%$ solution) titrated by $i v$ infusion to maintain a mean arterial pressure between $55 \mathrm{mmHg}$ and $65 \mathrm{mmHg}$. Following microscopic examination of the tympanic membrane, the surgeon injected lidocaine 1\% containing 1:200,000 adrenaline $\left(1 \mathrm{ml} \cdot 10 \mathrm{~kg}^{-1}\right)$ subcutaneously behind the auricle. At the end of surgery, the glyceryl trinitrate infusion was discontinued and residual neuromuscular blockade reversed with $0.035 \mathrm{mg} \cdot \mathrm{kg}^{-1}$ neostigmine and 0.017 $\mathrm{mg} \cdot \mathrm{kg}^{-1}$ atropine. Nalbuphine $\left(0.1 \mathrm{mg} \cdot \mathrm{kg}^{-1}\right.$ iv or 0.2 $\left.\mathrm{mg} \cdot \mathrm{kg}^{-1} \mathrm{im}\right)$ paracetamol $\left(10 \mathrm{mg} \cdot \mathrm{kg}^{-1} \mathrm{po}\right)$ and prochlorperazine $\left(0.2 \mathrm{mg} \cdot \mathrm{kg}^{-1} \mathrm{im}\right)$ were prescribed for 
TABLE I Patient characteristics and Perioperative anaesthetic data

\begin{tabular}{|c|c|c|c|c|}
\hline & Saline & im Prochlorperazine & iv Prochlorperazine & iv Ondansetron \\
\hline Patient numbers & 37 & 37 & 37 & 37 \\
\hline $\operatorname{Sex}(M: F)$ & $21: 16$ & $19: 18$ & $20: 17$ & $19: 18$ \\
\hline Age (yr) mean (SD) & $28.1(11.5)$ & $29.4(13.5)$ & $31.5(14.6)$ & $29.8(13.5)$ \\
\hline Age $(y r)$ range & $9-51$ & $9-53$ & $8-61$ & $7-58$ \\
\hline Weight (kg) & $64.1(18.4)$ & $61.9(20.2)$ & $66.8(19.7)$ & $58.4(21.7)$ \\
\hline History of MS & 1 & 2 & 1 & 2 \\
\hline History of PONV & 5 & 4 & 4 & 5 \\
\hline Duration of surgery (min) & $98.1(45.3)$ & $100.5(53.3)$ & $115.0(59.2)$ & $90.2(30.6)$ \\
\hline \multicolumn{5}{|l|}{ Recovery ward } \\
\hline - time (min) & $33.3(16.7)$ & $37.1(14.6)$ & $33(11)$ & $28(8)$ \\
\hline - nalbuphine & .0 & $1(3 \%)$ & $1(3 \%)$ & $0(0 \%)$ \\
\hline - prochlorperazine & $1(3 \%)$ & $0(0 \%)$ & $0(0 \%)$ & $0(0 \%)$ \\
\hline - vomiting & $6(16 \%)$ & $2(5 \%)$ & $3(8 \%)$ & $3(8 \%)$ \\
\hline \multicolumn{5}{|l|}{ Surgical ward } \\
\hline - nalbuphine & $5(22 \%)$ & $7(26 \%)$ & $4(17 \%)$ & $4(17 \%)$ \\
\hline - paracetamol & $19(78 \%)$ & $20(74 \%)$ & $19(83 \%)$ & $20(83 \%)$ \\
\hline - prochlorperazine & $9(24 \%)$ & $3(8 \%)$ & $6(16 \%)$ & $6(16 \%)$ \\
\hline
\end{tabular}

Data given as mean (SD) or number (percentage). MS = motion sickness; PONV = postoperative nausea and vomiting. No between group statistical differences.

administration by nurses, at their discretion, in the recovery and postoperative surgical wards to treat postoperative pain and emesis.

The test drugs were coded and, to ensure blindness, the anaesthetic chart was appropriately endorsed. All data were recorded on customised forms in the operating theatre, recovery and surgical wards. Before induction of anaesthesia a note was made of patient details, test drug group and baseline heart rate (HR), systolic, diastolic and mean (SAP, DAP, MAP) arterial pressures. At the termination of surgery and anaesthesia the duration of surgery was noted, as well as any vomiting or retching immediately after extubation. Nurses in the recovery ward, blind to the test drug given, recorded details of vomiting, retching, extrapyramidal movements, antiemetic and analgesic requirements. Nausea was not enquired into because of the difficulty of eliciting this complaint from drowsy Arabic speaking patients by our English speaking British and Philipino nurses.

During the first $24 \mathrm{hr}$ after surgery note was made by nurses, also unaware of the test drug given, of nausea, retching or vomiting reported to them. The time of onset of the complaint was recorded, and whether retching and vomiting was a single or repeated episode. ${ }^{13}$ They also recorded details of antiemetic and analgesic drugs given (nature, time of administration and whether given to treat nausea, retching, vomiting or headache, surgical pain or pyrexia, respectively) and the occurrence of extrapyramidal signs (tremors, involuntary movements, muscle spasms or rigidity). On the day after surgery the author, conversant in Arabic but also blinded to the drug given intraoperatively, visited the ward to review drug, fluid balance and nursing records, and to interview each patient and/or their relative or guardian with respect to nausea, retching, vomiting and headache (other than earache related to surgery).

Data were analysed using unpaired Students $t$ and Chi-squared tests with Yates' correction where appropriate. Chi-squared tests were used to test for differences in nausea, vomiting and postoperative drug requirement incidences. The effects of the antiemetics in modifying the severity of vomiting were assessed using Chi-squared tests after grouping the vomiters in each test group into single and multiple vomiters. Student $t$ tests were used to compare the mean times of occurrence of any symptom of PONV. Retching and vomiting were considered as similar morbidities and analysed collectively. $P<0.05$ was considered significant.

\section{Results}

\section{Comparability of test groups}

One hundred and forty eight consecutive patients aged between 7 and $61 \mathrm{yr}$ presenting for tympanoplasty were studied between the period January 1994 and August 1995. The study population comprised four groups of 37 patients, that were comparable for sex, age, weight, duration of anaesthesia, time spent in the recovery ward, need for analgesia and antiemesis in the recovery ward, and need for analgesia and antiemesis during the first 24 hr after surgery (Table I). Vomiting or retching immediately after extubation or during recovery from anaesthe- 
TABLE II Surgical ward. Distribution of patients experiencing postoperative nausea, vomiting, nausea with vomiting and no nausea or vomiting

\begin{tabular}{|c|c|c|c|c|c|c|c|c|c|c|c|c|}
\hline \multirow[b]{3}{*}{ Morbidity } & \multicolumn{12}{|c|}{ Test drug group } \\
\hline & \multicolumn{3}{|c|}{ Saline (placebo) } & \multicolumn{3}{|c|}{ im Prochlorperazine } & \multicolumn{3}{|c|}{ iv Prochlorperazine } & \multicolumn{3}{|c|}{ iv Ondansetron } \\
\hline & $N$ & $n$ & $\%$ & $N$ & $n$ & $\%$ & $N$ & $n$ & $\%$ & $N$ & $n$ & $\%$ \\
\hline Nausea & 36 & 2 & 5 & 37 & 3 & 8 & 37 & 3 & 3 & 37 & 3 & 8 \\
\hline$P$ (versus placebo) & & & & & $\mathrm{ns}$ & & & ns & & & ns & \\
\hline Vomiting & 37 & 6 & 16 & 37 & 7 & 19 & 37 & 9 & 24 & 37 & 4 & 11 \\
\hline$P$ value (versus placebo) & & & & & $\mathrm{ns}$ & & & ns & & & ns & \\
\hline Nausea with vomiting & 36 & 19 & 53 & 37 & 6 & 16 & 37 & 11 & 30 & 37 & 7 & 19 \\
\hline$P$ value (versus placebo) & & & & & $<0$. & & & $<0.05$ & & & & \\
\hline No PONV & 37 & 10 & 27 & 37 & 21 & 57 & 37 & 14 & 43 & 37 & 23 & 62 \\
\hline$P$ value (versus placebo) & & & & & $<0$ & & & ns & & & & \\
\hline
\end{tabular}

$\mathrm{N}=$ patient numbers; $n=$ number of complainants.

TABLE III Time to onset of PONV (mean, standard deviation) and severity of vomiting (single vs multiple vomiters)

\begin{tabular}{|c|c|c|c|c|}
\hline & iv Saline & im Prochlorperazine & iv Prochlorperazine & iv Ondansetron \\
\hline \multicolumn{5}{|l|}{ Onset of PONV } \\
\hline Number experiencing nausea or vomiting & 27 & 16 & 21 & 14 \\
\hline Time to onset (hr) & $4.63(1.90)$ & $7.28(4.01)^{*}$ & $6.27(3.69)$ & $4.69(2.6)$ \\
\hline \multicolumn{5}{|l|}{ Severity of vomiting } \\
\hline Patient numbers & 37 & 37 & 37 & 37 \\
\hline Total number vomiting & $2568 \%$ & $1335 \%$ & $2054 \%$ & $1130 \%$ \\
\hline - single episode & $525 \%$ & $646 \%$ & $1050 \%$ & $764 \% *$ \\
\hline - multiple episode & $2075 \%$ & $754 \%$ & $1050 \%$ & $436 \% *$ \\
\hline
\end{tabular}

$* P<0.025$ compared with placebo.

sia occurred in $16 \%$ of the placebo group, $5 \%$ of those given im prochlorperazine and in $8 \%$ each of those given prochlorperazine $i v$ or ondansetron iv $(P>0.05$ all comparisons, Chi-squared).

\section{Postoperative nausea, vomiting and headache}

A failure on the part of a nine-year-old Arabic-speaking boy in the saline (placebo) group to reply unequivocally to questions at the postoperative interview regarding the occurrence of nausea or headache resulted in only 36 sets of nausea and headache data in this group. The incidences of nausea alone during the first $24 \mathrm{hr}$ postoperative period were similar and infrequent (between 3 and $8 \%$ ) in each treatment group. The incidences of vomiting alone (without accompanying nausea) during this time were also similar ( 11 to $24 \%$ ). However, the incidence of nausea accompanied by vomiting was reduced from $53 \%$ (placebo) to $16 \%$ and $19 \%$ in those given prochlorperazine $i m$ and ondansetron $i v$ respectively $(P$ $<0.0005$, both comparisons, Chi-squared), and to $30 \%$ in those given prochlorperazine iv $(P<0.05$, Chisquared). The number of patients experiencing no nau- sea or vomiting in the four test groups were placebo $10(27 \%)$, prochlorperazine im $21(57 \%)$, prochlorperazine iv 14(43\%) and ondansetron iv 14 (62\%), of which only the lower incidence in those given prochlorperazine $i m$ and ondansetron $i v$ attained significance. $(P<$ 0.01 and $P=0.005$, Chi-squared, respectively; Table II).

The onset of any complaint of postoperative nausea or vomiting occurred later in those given prochlorperazine im $(P<0.025)$ and prochlorperazine iv $(P<0.1)$, but was unaffected by ondansetron $i v$. Both prochlorperazine treatments and ondansetron iv modified the severity of vomiting by reducing the incidence of patients experiencing multiple vomits, from $75 \%$ to 54,50 and $36 \%$ respectively, but only the latter reduction attained significance $(P<0.025$ Chi-squared; Table III).

The incidence of headache reported during the first $24 \mathrm{hr}$ after surgery (placebo $56 \%$, prochlorperazine im $41 \%$,prochlorperazine iv $43 \%$ and ondansetron iv 49\%) were similar in the four test groups.

\section{Discussion}

This double blind, placebo controlled, randomised 
prospective study was conducted to determine the effects of prochlorperazine $0.2 \mathrm{mg} \cdot \mathrm{kg}^{-1} \mathrm{im}$, prochlorperazine $0.1 \mathrm{mg} \cdot \mathrm{kg}^{-1} i v$ and ondansetron $0.06 \mathrm{mg} \cdot \mathrm{kg}^{-1}$ iv given with induction of anaesthesia on PONV and post-operative headache following general anaesthesia for tympanoplasty. Prochlorperazine im and ondansetron iv were similarly and powerfully efficacious in reducing the incidence of nausea with vomiting after middle ear surgery, while prochlorperazine iv caused a smaller reduction in this index of PONV. Neither of the prochlorperazine treatments was associated with iatrogenic extrapyramidal reactions, and ondansetron iv did not result in a higher incidence of postoperative headache. Prochlorperazine $i m$ delayed the onset of any symptom of PONV, and ondansetron reduced the severity of postoperative vomiting.

The failure of prochlorperazine $0.1 \mathrm{mg} \cdot \mathrm{kg}^{-1}$ iv to demonstrate a more powerful antiemetic efficacy was surprising as previous studies have shown this treatment to be as effective as the larger dose given $\mathrm{im} .{ }^{4}$ The ineffectiveness may simply be attributable to the smaller dose administered $i v$. However, this dose lies within the range recommended in North America (Compazine; Smith Kline and Beecham; prochlorperazine edisylate; 5 to $10 \mathrm{mg}$ iv or $\mathrm{im},{ }^{14}$ and was chosen to avoid the possibility of hypertension, hypotension and extrapyramidal reactions which may have followed $i v$ administration of the larger dose as recommended for im administration by its European manufacturers (Stemetil; Rhône Poulenc Rorer; prochlorperazine mesylate; $12.5 \mathrm{mg}$ im)..$^{11,14,15}$

The size of the population studied provides sufficient power to suggest that failure of the smaller dose of prochlorperazine $i v$ to exhibit more impressive antiemetic efficacy is a true indication of its relative lack of efficacy when so given. However, analysis of times of onset and severity of symptoms were performed on the small numbers of those who did become nauseated, retched or vomited. These sample sizes are too small to provide statistical significance to the observations that prochlorperazine iv delayed the onset of PONV and that either prochlorperazine treatment reduced the severity of vomiting. A delay in the onset of PONV in those given prochlorperazine, and not in those given ondansetron, may be anticipated as prochlorperazine has a half-life after parenteral administration of $23 \mathrm{hr},{ }^{16}$ whilst ondansetron has a half life after $i v$ administration of 3.5 to $5.5 \mathrm{hr}^{17}$

Numerous surgical procedures on the head, neck and torso may reflexly stimulate the vagal brain stem nucleus to produce laryngospasm, ${ }^{18}$ bradydysrhythmias ${ }^{19-23}$ or emesis. ${ }^{24-26}$ The sensory nerve supply of the auricle, external auditory meatus, tympanic membrane, middle ear cleft and inner ear is provided by the $\mathrm{V}$ (trigeminal),
VII (facial), VIII (vestibular, cochlear), IX (glossopharyngeal) and $\mathrm{X}$ (vagus) cranial nerves, and the second and third cervical nerves $\left(\mathrm{C}_{2} \mathrm{C}_{3}\right) \cdot{ }^{27,28}$ In this hospital, vomiting following ear, nose and throat surgery occurs most frequently aftere tympanoplasty (c. $60 \%$ of patients); less frequently after septorhinoplasty (c. $40 \%$ of patients), and least frequently after tonsilloadenoidectomy (c. $30 \%$ of patients). The high incidence of PONV in those undergoing middle ear surgery is very likely due to augmentation of the normal base vomiting rate expected after anaesthesia by vomiting reflexes mediated via the vagus. ${ }^{3,26}$

Headache following ear, nose and throat surgery in this hospital occurs most frequently following septorhinoplasty (c. $75 \%$ of patients), less frequently after tympanoplasty (c. $50 \%$ of patients and least frequently after tonsilloadenoidectomy (c. $33 \%$ of patients). ${ }^{1,2}$ Ondansetron given as prophylactic antiemetic to patients undergoing chemo- and radiotherapy causes headache in $11 \%$ of patients, ${ }^{6}$ but when given as prophylactic antiemetic to patients undergoing general anaesthesia does not appear to increase the incidence of postoperative headache. ${ }^{8,10,29}$ In the present study the incidence of headache after tympanoplasty in patients given ondansetron $(49 \%)$ was similar to that after placebo $(50 \%)$, prochlorperazine im $(41 \%)$, prochlorperazine iv $(43 \%)$ and after tympanoplasty in our previous studies $(50 \%))^{1,2}$ These data suggest that ondansetron given with anaesthesia does not increase the incidence of postoperative headache.

Postoperative nausea and vomiting following microsurgery of the middle ear has been a problem since the introduction of this surgical technique in the early 1950s. Traditionally, hyoscine or promethazine im with premedication have been recommended for its prophylaxis, ${ }^{30,31}$ and thiethylperazine, because of its effectiveness in vertigo, ${ }^{\prime \prime}$ for its treatment. More recently, with the decline in popularity of im pre-medication, transdermal hyoscine has been shown to be effective in reducing the incidence after tympanoplasty of postoperative nausea (from $27 \%$ to $10 \%$ ), and of postoperative vomiting from $(53 \%$ to $10 \%){ }^{26}$

This study confirms the observation that PONV is a frequent and debilitating complication after tympanoplasty, ${ }^{1,2,26}$ and demonstrates that prochlorperazine $0.2 \mathrm{mg} \cdot \mathrm{kg}^{-1}$ im and ondansetron $0.06 \mathrm{mg} \cdot \mathrm{kg}^{-1}$ iv given during induction of anaesthesia are efficacious in reducing this morbidity. Depending on cost restraints and availability, it is suggested that patients undergoing tympanoplasty receive either prochlorperazine im or ondansetron $i v$ with induction of anaesthesia or transdermal hyoscine with premedication to minimise PONV pending a comparison of these treatments. 


\section{Acknowledgements}

The author is indebted to Drs. S. Bandy, M. Rabiah and H. Al Nasser (Consultant Ear, Nose and Throat Surgeons); Dr. E. Halliday, D. Savva and F. El Gohary (Consultant Anaesthetists); the Nursing Staff of the Recovery (post-anaesthetic) and Surgical Wards; Mrs. I. Beime, Ms C. Drummond and Ms. P. Boylan (Department of Anaesthesia); Charge Nurse L. Nina (translation) and Glaxo Laboratories for their combined contributions to this project.

\section{References}

1 van den Berg AA, Honjol NM, Rama Prabhu NV, et al. Analgesics and ENT Surgery. A clinical comparison of the intraoperative, recovery and postoperative effects of buprenorphine, diclofenac, fentanyl, morphine, nalbuphine, pethidine and placebo given intravenously with induction of anaesthesia. Br J Clin Pharmacol 1994; 38: 533-43.

2 van den Berg AA, Savva D, Honjol NM, Rama Prabhu NV. A comparison of total intravenous, balanced inhalational and combined intravenous - inhalational anaesthesia for tympanoplasty, septorhinoplasty and adenotonsillectomy. Anaesth Intensive Care 1995; 23: 574-82.

3 Rowbotham DJ. Current management of postoperative nausea and vomiting. Br J Anaesth 1992; 69: 46S-59S.

4 van den Berg AA, Lambourne A. Prochlorperazine and vomiting after eye surgery (Letter). Anaesthesia 1987; 42: 898.

5 Tyers MB, Bunce KT, Humphrey PPA. Pharmacological and anti-emetic properties of ondansetron. European Journal of Cancer and Clinical Oncology 1989: 25: S15-S19.

6 Dicato MA, Freeman AJ. Experience with ondansetron in chemotherapy - and radiotherapy - induced emesis. Eur J Anaesthesiol 1992; 9(Suppl 6): 19-24.

7 Zofran. Glaxo Laboratories, Middlesex, England. Product information.

8 Raphael JH, Norton AC. Antiemetic efficacy of prophylactic ondansetron in laparoscopic surgery: randomised, double-blind comparison with metoclopramide. $\mathrm{Br} \mathrm{J}$ Anaesth 1993; 71: 845-8.

9 Alon E, Himmelseher $S$. Ondansetron in the treatment of postoperative vomiting: a randomised, double-blind comparison with droperidol and metoclopramide. Anaesth Analg 1992; 75: 561-5.

10 Kovac A, McKenzie R, O'Connor T, et al. Prophylactic intravenous ondansetron in female outpatients undergoing gynaecological surgery: a multicentre dose-comparison study. Eur J Anaesthesiol 1992; 9(Suppl 6): 37-47.

11 Reynolds JEF. Anxiolytics, sedatives, hypnotics \& neuroleptics. In: Reynolds JEF (Ed.). Martindale. The Extra Pharmacopoeia, 29th ed. London: The Pharmaceutical Press, 1989; 706-76.
12 van den Berg AA, Honjol NM, Parmar N. ENT and eye anaesthesia: to spray or not to spray - a rationalisation (Letter). Anaesthesia 1993; 48: 742.

13 van den Berg AA, Lambourne A, Yazji NS, Laghari NA. Vomiting after ophthalmic surgery. Effects of intra-operative antiemetics and postoperative oral fluid restriction. Anaesthesia 1987; 42: 270-6.

14 McEvoy GK. American Hospital Formulary Service Drug Information 1995. Bethesda, MD 21814: American Society of Health System Pharmacists 1995: 1517-8.

15 Roche $H$, Hyman $G$, Nahas $G$. Hypertension and intravenous antidopaminergic drugs (letter). $\mathrm{N}$ Eng J Med 1985: 312: 1125-6.

16 Vožeh S, Schmidlin $O$. Pharmacokinetic drug data. In: Speight TM (Ed.). Avery's Drug Treatment. Principles and Practice of Clinical Pharmacology and Therapeutics, 3rd ed. Auckland: Adis Press Ltd, 1987; 1352-80.

17 Baber N, Palmer JL, Frazer NM, Pritchard JF. Clinical pharmacology of ondansetron in postoperative nausea and vomiting. Eur J Anaesthesiol 1992; 9(Suppl 6): 11-8.

18 Wood PR, Foley MA, Lawler PG. Vagal reflexes and anaesthesia. Br J Hosp Med 1990; 44: 137-9.

19 Dagnini G. Intorno ad un riflesso provocato in alcuni emiplegici collo stimolo della cornea e colla pressione sul bulbo oculare. (Italian) Bol Della Sc Med 1908; 8: 380-3.

20 Shearer ES, Wenstone $R$. Bradycardia during elevation of zygomatic fractures. A variation of the oculocardiac reflex. Anaesthesia 1987; 42: 1207-8.

21 Hopkins CS. Bradycardia during neurosurgery - a new reflex? (Letter) Anaesthesia 1988; 43: 157-8.

22 Baxendall $M L$, Thorn $J L$. The nasocardiac reflex. Anaesthesia 1988; 43: 480-1.

23 Davies A. Bradycardia and asystole associated with trigeminal ganglion injection (Letter). Anaesthesia 1988; 43: 895 .

24 van den Berg AA, Lambourne A, Clyburn PA. The oculoemetic reflex. A rationalisation of postophthalmic anaesthesia vomiting. Anaesthesia 1989; 44: 110-7.

25 Mansour NY. Auriculo-emetic reflex? (Letter) Anaesthesia 1989; 44: 934.

26 Honkavaara P, Saarnivaara L, Klemola U-M. Prevention of nausea and vomiting with transdermal hyoscine in adults after middle ear surgery during general anaesthesia. Br J Anaesth 1994; 73: 763-6.

27 Surgical anatomy of the temporal bone. In: Glasscock ME III, Shambaugh GE Jr, Johnson GD (Eds.). Surgery of the Ear, 4th ed. Philadelphia: WB Saunders Company, 1990: 34-53.

28 Wright A. Anatomy and ultrastructure of the human ear. In: Kerr AF, Groves J (Eds.). Scott Brown's Otolaryngology, 5th ed. London: Butterworths, 1987: $1-46$.

$29 \mathrm{Du}$ Peu S, Scuderi P, Wetchler B, et al. Ondansetron in 
the treatment of postoperative nausea and vomiting in ambulatory patients: a dose-comparative, stratified, multicentre study. Eur J Anaesthesiol 1992; 9(Suppl 6): 55-62.

30 Barron DW. Anaesthesia for microsurgery of the ear. In: Morrow WFK, Morrison JD (Eds.). Anaesthesia for Eye, Ear, Nose and Throat Surgery. Edinburgh: Churchill Livingstone, 1975: 105-11.

31 Mathias JA. Anaesthesia for special situations. In: Churchill-Davidson HC (Ed.). Wylie and ChurchillDavidson's A Practice of Anaesthesia, 5th ed. London: Lloyd-Luke (Medical Books) Ltd, 1984: 142-56. 